\title{
Determination of Lead Elemental Concentration and Isotopic Ratios in Coal Ash and Coal Fly Ash Reference Materials Using Isotope Dilution Thermal Ionization Mass Spectrometry
}

\author{
Chaofeng Li ${ }^{1,2, *}$, Huiqian $\mathrm{Wu}^{1,2,3}$, Xuance Wang ${ }^{4,5}$, Zhuyin Chu ${ }^{1,2}$, Youlian $\mathrm{Li}^{1,2}$ and \\ Jinghui Guo ${ }^{1,2}$ \\ 1 State Key Laboratory of Lithospheric Evolution, Institute of Geology and Geophysics, \\ Chinese Academy of Sciences, Beijing 100029, China; wuhuiqian17@mails.ucas.edu.cn (H.W.); \\ zhychu@mail.iggcas.ac.cn (Z.C.); lyl@mail.iggcas.ac.cn (Y.L.); jhguo@mail.iggcas.ac.cn (J.G.) \\ 2 Innovation Academy for Earth Science, Chinese Academy of Sciences, Beijing 100029, China \\ 3 University of Chinese Academy of Sciences, Beijing 100049, China \\ 4 Research Centre for Earth System Science, Yunnan Key Laboratory of Earth System Science, \\ Yunnan University, Kunming 650500, China; xuancewang@mail.iggcas.ac.cn \\ 5 School of Earth and Environmental Sciences, The University of Queensland, Brisbane, QLD 4072, Australia \\ * Correspondence: cfli@mail.iggcas.ac.cn; Tel.: +86-10-8299-8583
}

Received: 25 October 2019; Accepted: 23 November 2019; Published: 28 November 2019

\begin{abstract}
The rapid expansion of coal-fired power plants around the world has produced a huge volume of toxic elements associated with combustion residues such as coal fly ash (CFA) and coal ash (CA), which pose great threats to the global environment. It is therefore crucial for environmental science to monitor the migration and emission pathway of toxic elements such as CFA and CA. Lead isotopes have proved to be powerful tracers capable of dealing with this issue. Unfortunately, up to now, few high precision lead isotope data of CFA and CA certified reference materials (CRMs) determined by using the double spike technique have been reported. Hence, to facilitate the application of lead isotopes in environmental science, it is indispensable and urgent to determine a suite of high precision $\mathrm{Pb}$ isotope ratios and $\mathrm{Pb}$ elemental contents for CFA and CA CRMs. Here, we measured lead isotope ratios from four CFA and CA CRMs using thermal ionization mass spectrometry (TIMS) combined with the ${ }^{204} \mathrm{~Pb}-{ }^{207} \mathrm{~Pb}$ double spike method. Lead isotope ratios values of CRMs (GBW11124, GBW08401, GBW11125d, and JCFA-1) covered wide variation ranges from 17.993 to 19.228 for ${ }^{206} \mathrm{~Pb} /{ }^{204} \mathrm{~Pb}$, from 15.513 to 15.675 for ${ }^{207} \mathrm{~Pb} /{ }^{204} \mathrm{~Pb}$, and from 38.184 to 39.067 for ${ }^{208} \mathrm{~Pb} /{ }^{204} \mathrm{~Pb}$. Lead isotope ratios of these CRMs, except for GBW11124, show good external reproducibility ( $2 \mathrm{RSD}, \mathrm{n}=8$ ), which is better than $0.05 \%$ for ${ }^{206} \mathrm{~Pb} /{ }^{204} \mathrm{~Pb}$ and ${ }^{207} \mathrm{~Pb} / 204 \mathrm{~Pb}, 0.07 \%$ for ${ }^{208} \mathrm{~Pb} /{ }^{204} \mathrm{~Pb}, 0.04 \%$ for ${ }^{206} \mathrm{~Pb} /{ }^{207} \mathrm{~Pb}$, and $0.05 \%$ for ${ }^{208} \mathrm{~Pb} /{ }^{206} \mathrm{~Pb}$. The $\mathrm{Pb}$ concentrations of these $\mathrm{CRMs}$ were determined using ${ }^{207} \mathrm{~Pb}$ single spike method. The reproducibility ( $1 \mathrm{RSD}, \mathrm{n}=4$ ) of Pb elemental content was $<0.60 \%$. This indicates the distribution of $\mathrm{Pb}$ elements in these CRMs is homogeneous. With the exception of GBW11124, the suite of CRMs can be used for determining CFA and CA matrix composition for quality control of $\mathrm{Pb}$ isotope analyses.
\end{abstract}

Keywords: $\mathrm{Pb}$ isotope; coal fly ash; coal ash; ${ }^{204} \mathrm{~Pb}-{ }^{207} \mathrm{~Pb}$ double spike; TIMS

\section{Introduction}

Accumulation of toxic metals, such as lead $(\mathrm{Pb})$, chromium $(\mathrm{Cr})$, and cadmium $(\mathrm{Cd})$, in the human body from rapid industrialization and urbanization can lead to a range of health problems and increase 
the risk of cancer once the safe dose levels are exceeded [1]. Especially for lead, often known as a "chemical time bomb" due to its known toxicity, lead contamination can cause adverse effects on nervous, hemopoietic, cardiovascular, and endocrine systems in the human body [2]. In ecosystems, lead is one of the most common anthropogenic contaminants, which is primarily generated by combustion of coal, vehicle emissions, and smelting of nonferrous metals [3]. As one of the classical fossil fuels in industrialization and urbanization history, coal has been the foundation of energy generation since the industrial revolution in the late 18th century. According to EIA's International Energy Outlook 2008 [4], fossil fuels currently account for $86 \%$ of the primary energy demand (36\% oil, $27 \%$ coal, and $23 \%$ natural gas), whereas renewable sources (solar, wind, geothermal, biomass, and hydroelectricity) only account for about $8 \%$, and nuclear power for about $6 \%$. Clearly, thus far, coal is still the primary fuel resource for global electricity production in many countries around the world [4-6]. In 2011, coal-fired generation accounted for $29.9 \%$ of the world's electricity supply, and its share is anticipated to be $46 \%$ by 2030 [7]. It is estimated that coal-fired power facilities around the world generate 780 million tons of CCW (coal combustion waste) each year [6]. The most common forms of CCW include both coal ash (CA) and coal fly ash (CFA) that are industrial byproducts and derived from coal combustion in thermal power plants.

As the world's largest producer and consumer of coal [3,7], China accounted for 50.2\% [7] of the world coal consumption in 2012 and therefore is seriously contributing to atmospheric $\mathrm{Pb}$ pollution due to the large emission of $\mathrm{Pb}(\sim 46,300$ tons during the period of 1990-2009) from coal combustion [8]. As one of the most hazardous elements in coal, $\mathrm{Pb}$ can be released into the environment during coal mining, processing, and utilization. During coal combustion or pyrolysis, $\mathrm{Pb}$ is partly emitted into the atmosphere and partly partitioned into solid residues as CCW. The accumulation of large amounts of ash from coal combustion for electric power plant generation may cause serious contamination of $\mathrm{Pb}$ and other heavy metals [9-16] (such as $\mathrm{As}, \mathrm{Hg}, \mathrm{Ni}, \mathrm{Cd}$, and $\mathrm{Cr}$ ) in groundwater, soil, and air, thus becoming a major environmental concern in China [2,3,8]. Hence, identification and tracing of the source of $\mathrm{Pb}$ contamination $[2,3,8]$, the timing of its release, and its pollutant transport pathway and distribution into the environment are crucial issues in investigation of CA and CFA pollution.

In contrast to the other isotopic indicators, such as $\mathrm{Li}$ [17], $\mathrm{Hg}$ [18], B [19], $\mathrm{Sr}$ [19-22], $\mathrm{Nd}$ [22], etc., there is no doubt that $\mathrm{Pb}$ isotope is a more sensitive indicator in directly tracing $\mathrm{Pb}$ contamination transport pathways. There are four naturally occurring stable $\mathrm{Pb}$ isotopes $\left({ }^{204} \mathrm{~Pb},{ }^{206} \mathrm{~Pb},{ }^{207} \mathrm{~Pb}\right.$, and ${ }^{208} \mathrm{~Pb}$ ). Their abundance varies because of different decay pathways from ${ }^{238} \mathrm{U},{ }^{235} \mathrm{U}$, and ${ }^{232} \mathrm{Th}$ to ${ }^{206} \mathrm{~Pb},{ }^{207} \mathrm{~Pb}$, and ${ }^{208} \mathrm{~Pb}$, respectively. Different types of rock, ore deposits, and anthropogenic sources have their own distinct $\mathrm{Pb}$ isotopic fingerprint. Due to their stability during physical and chemical processes, the isotopic composition of $\mathrm{Pb}$ are not affected by industrial or environmental processing, and retain their original characteristic ratio from their source [3-23]. Therefore, lead isotopic ratios can be used as an ideal "fingerprint" to directly identify lead sources and investigate lead pollution pathways in various environmental media, such as soil, sediments, atmosphere particles, coal, coal ash, and coal fly ash [3-23].

Certified reference materials (CRMs) play an important role in isotope ratio and elemental content analysis because CRMs are the prerequisite to examine the quality of data for unknown analysis objects $[22,24,25]$. In previous studies, analysts have reported many trace element data for coal, coal fly ash, and coal ash CRMs [26-28]. However, few high precision Pb elemental contents and the isotope ratios of CA and CFA CRMs have been reported. To monitor lead isotope data of CA and CFA samples in previous studies, silicate CRMs were employed to evaluate the quality for actual CA and CFA samples. This is an eclectic analytical scheme because the matrix composition of CA and CFA is different from silicate CRMs. CA and CFA samples are composed of amorphous inorganic components, minerals (e.g., silicates, oxides, hydroxides mainly of iron, sulfates, carbonates, phosphates, and sulfides), and organic constituents or unburnt coal [15]. To obtain accurate elemental contents or isotope ratios through bulk analysis, the best method is to employ the same type of CRMs 
to verify the actual analytical objects. Therefore, it is crucial to report the $\mathrm{Pb}$ isotope composition and $\mathrm{Pb}$ elemental content of CFA and CA CRMs.

This study is the first to report high precision $\mathrm{Pb}$ isotope ratio data for CA and CFA CRMs using the ${ }^{204} \mathrm{~Pb}-{ }^{207} \mathrm{~Pb}$ double spike method by thermal ionization mass spectrometry (TIMS). We believe that, by integrating $\mathrm{Pb}$ isotope data of the suite of CRMs from this study with our previously reported $\mathrm{Sr}$ and $\mathrm{Nd}$ isotope data [22], researchers can conduct more precise investigations when tracing lead emissions resulting from anthropogenic activities and also investigate the temporal and spatial variations of lead emissions in China. This will play a key role in estimating the lead emissions from different sources, and in identifying the sectors that should control lead emissions.

\section{Experimental}

\subsection{Reagents and Materials}

The analytical grade acids ( $8 \mathrm{M} \mathrm{HBr}, 29 \mathrm{M} \mathrm{HF}, 14 \mathrm{M} \mathrm{HNO}_{3}$, and $12 \mathrm{M} \mathrm{HCl}$ ) used in this study were obtained from the China National Pharmaceutical Group Corporation and further purified by sub-boiling distillation using a DST-1000 PFA apparatus (Savillex Corporation, Eden Prarie, MN, USA). To reduce the chemical blanks of lead, ultra-pure water generated by a Milli-Q Element system was used in this work. The Bio-Rad AG1-X8 anion resin was used to separate $\mathrm{Pb}$ with high purity from $\mathrm{CA}$ and CFA matrix. A solution of $10 \mathrm{ppm} \mathrm{Pb}$ of NIST SRM981 was gravimetrically prepared to monitor the status of Triton Plus thermal-ionization mass spectrometer (TIMS). The isotopically enriched tracers included ${ }^{207} \mathrm{~Pb}(92.813 \%)$ and ${ }^{204} \mathrm{~Pb}(82.571 \%)$ were obtained from Oak Ridge National Laboratory USA. Single-element powders of these isotope tracers were weighed (to $0.01 \mathrm{mg}$ precision) and dissolved by heating in $6 \mathrm{M} \mathrm{HCl}$. Portions of these isotope tracer solutions were mixed appropriately to obtain the mixed ${ }^{204} \mathrm{~Pb}-{ }^{207} \mathrm{~Pb}$ tracers. The ${ }^{204} \mathrm{~Pb}-{ }^{207} \mathrm{~Pb}$ double spike solution was diluted to $1.011 \mathrm{ppm}$ and calibrated using NIST SRM-981. The ${ }^{204} \mathrm{~Pb}-{ }^{207} \mathrm{~Pb}$ double spike was employed to measure the lead isotope ratios of CRMs. The ${ }^{207} \mathrm{~Pb}$ isotope tracer was diluted to $0.501 \mathrm{ppm}$ and employed to measure the $\mathrm{Pb}$ elemental content of CRMs. The ${ }^{207} \mathrm{~Pb}$ single spike was calibrated using reverse isotope dilution against the standard solution of $10 \mathrm{ppm} \mathrm{Pb}$ of NIST SRM981. Table 1 lists the $\mathrm{Pb}$ isotopic compositions of the ${ }^{207} \mathrm{~Pb}$ single spike and the ${ }^{204} \mathrm{~Pb}-{ }^{207} \mathrm{~Pb}$ double spike.

Table 1. The compositions of used ${ }^{207} \mathrm{~Pb}$ spike and ${ }^{204} \mathrm{~Pb}^{-207} \mathrm{~Pb}$ double spike (atom\%).

\begin{tabular}{ccccc}
\hline Spikes & ${ }^{204} \mathbf{P b}$ & ${ }^{206} \mathbf{P b}$ & ${ }^{207} \mathbf{P b}$ & ${ }^{208} \mathbf{P b}$ \\
\hline${ }^{207} \mathrm{~Pb}$ & 0.1391 & 2.452 & 92.813 & 4.631 \\
${ }^{204} \mathrm{~Pb} \_{ }^{207} \mathrm{~Pb}$ & 40.165 & 1.555 & 55.457 & 2.823 \\
\hline
\end{tabular}

\subsection{Coal Fly Ash and Coal Ash Certificate Reference Materials}

In this study, four CA and CFA CRMs were measured. These CRMs included GBW11125d (coal ash), GBW11124 (coal ash), and GBW08401 (coal fly ash) from the Chinese National Research Centre for Certified Reference Materials (NRCCRM), and JCFA-1(coal fly ash) from the Geological Survey of Japan (GSJ). All CRMs are commercially available. Chinese CRMs can be obtained from Booming Technology Limited Inc. (http://www.boomingtec.com; email: tengqing2004@sina.com) and the Japanese CRM can be purchased from GSJ. (https://gbank.gsj.jp/geostandards/welcome.html; email: t-okai@aist.go.jp). Two basalt rock CRMs (JB-3 and BCR-2) from the GSJ and the USGS were employed to verify $\mathrm{Pb}$ isotope composition and $\mathrm{Pb}$ elemental content during sample digestion, chemical separation and TIMS measurement.

\subsection{Sample Digestion}

To avoid the potential contamination of CFA and CA samples during sample digestion and chemical separation, all sample treatments were carried out in a class 1000 clean laboratory. All samples 
were digested twice individually for $\mathrm{Pb}$ elemental content measurement and $\mathrm{Pb}$ isotope composition measurement, respectively. The one adding a ${ }^{207} \mathrm{~Pb}$ single spike was for obtaining the content of $\mathrm{Pb}$. The other one without adding any spike was used to obtain high precision $\mathrm{Pb}$ isotope ratios. The unspiked sample after purification was divided into two aliquots, one measured directly and the other one was mixed with the ${ }^{204} \mathrm{~Pb}-{ }^{207} \mathrm{~Pb}$ double spike and measured $[29,30]$.

To determine the $\mathrm{Pb}$ elemental content and $\mathrm{Pb}$ isotope ratios, $100-105 \mathrm{mg}$ of powdered rock sample was weighed and added to a $7 \mathrm{~mL}$ round bottom Savillex Teflon screw-top capsule, and then an acid mixture of $3.0 \mathrm{~mL}$ of $29 \mathrm{M} \mathrm{HF}+0.3 \mathrm{~mL}$ of $14 \mathrm{M} \mathrm{HNO}_{3}$ was added and dissolved on a hotplate at $180^{\circ} \mathrm{C}$ for four days. After cooling, the capsule was opened and evaporated to dryness at ca. $120^{\circ} \mathrm{C}$. Then, the sample was re-dissolved once more in $1.0 \mathrm{~mL}$ of $6 \mathrm{M} \mathrm{HCl}$ and reheated to $180^{\circ} \mathrm{C}$ for $3 \mathrm{~h}$ to destroy fluoride complexes. Finally, the vials were opened and the resulting sample solution was evaporated to dryness and then re-dissolved with $1.0 \mathrm{~mL}$ of $0.7 \mathrm{M} \mathrm{HBr}$ on a hotplate at $120^{\circ} \mathrm{C}$.

\subsection{Pb Purification Using Column Chemistry and Procedural Blank}

Table 2 lists the detailed separation procedure for $\mathrm{Pb}$. The AG1-X8 anion resin column is used to obtain the $\mathrm{Pb}$ fraction with high purity from the $\mathrm{CA}$ and CFA matrix solution. As shown in Table 2, the resulting sample solutions obtained from the previous step were loaded into a small polyethene plastic column that is $4 \mathrm{~cm}$ long with a $2 \mathrm{~mm}$ i.d. and $2 \mathrm{~mL}$ reservoir, packed with $0.25 \mathrm{~mL}$ of Bio-Rad AG1-X8 anion resin (200-400 mesh). The column was pre-cleaned with $4.0 \mathrm{~mL} 6 \mathrm{M} \mathrm{HCl}, 5.0 \mathrm{~mL}$ Mill-Q $\mathrm{H}_{2} \mathrm{O}$, and $1.0 \mathrm{~mL} 0.7 \mathrm{M} \mathrm{HBr}$. Considering our small column capacity, only half of the sample solution $(0.50 \mathrm{~mL}$ of $0.7 \mathrm{M} \mathrm{HBr})$, was loaded into the AG1 column. When the sample solution was loaded into the AG1 anion resin exchange column in dilute hydrobromic acid, most matrix cations ( $\mathrm{Al}, \mathrm{Fe}, \mathrm{Na}, \mathrm{K}$, $\mathrm{Ti}, \mathrm{Mg}, \mathrm{Ca}, \mathrm{Mn}, \mathrm{Sr}, \mathrm{Ba}$, etc.) passed through the column without interacting with the anion exchanger, whereas the $\mathrm{Pb}$ were strongly retained on the AG1 resin. The resin column was then washed with a further $4.2 \mathrm{~mL}$ of $0.7 \mathrm{M} \mathrm{HBr}$ to remove the remaining unwanted matrix elements absorbed by AG1 anion resin. Finally, the $\mathrm{Pb}$ fraction was eluted using $1.2 \mathrm{~mL}$ of $6 \mathrm{M} \mathrm{HCl}$. The separation procedure of $\mathrm{Pb}$ using AG1 anion resin column in this study was similar to the previous method [31-34].

Table 2. Pb purification scheme using AG1-X8 resin.

\begin{tabular}{ccc}
\hline Procedure & Eluting Reagent & Eluting Volume (mL) \\
\hline Cleaning column & $6.0 \mathrm{M} \mathrm{HCl}$ & 4.0 \\
Cleaning column & Milli-Q Water & 5.0 \\
Cleaning column & $0.7 \mathrm{M} \mathrm{HBr}$ & 1.0 \\
Loading sample & $0.7 \mathrm{M} \mathrm{HBr}$ & 0.5 \\
Rinsing & $0.7 \mathrm{M} \mathrm{HBr}$ & 4.2 \\
Eluting Pb & $6.0 \mathrm{M} \mathrm{HCl}$ & 1.2 \\
\hline
\end{tabular}

The recovery yield of $\mathrm{Pb}$ was higher than $82 \%$. The whole procedure blank was lower than $140 \mathrm{pg}$ for $\mathrm{Pb}$. Hence, the ratio of CFA and CA sample over blank was never lower than 13,000 even for GBW08401 with relatively low content of $\mathrm{Pb}$. This shows that the blanks during sample digestion and column chemistry were negligible relative to the loading size containing an aliquot of 50.0-52.5 mg CA and CFA.

\subsection{Thermal Ionization Mass Spectrometry Measurement}

Lead isotopic measurements were conducted on a Thermo Triton Plus thermal ionization mass spectrometer (TIMS) equipped with nine Faraday collectors at the Institute of Geology and Geophysics, Chinese Academy of Sciences (IGGCAS). Faraday cup collectors with $10^{11} \Omega$ resistor were employed for $\mathrm{Pb}$ isotopic determinations. Re ribbon $(0.035 \mathrm{~mm}$ thick, $0.77 \mathrm{~mm}$ wide, and $99.98 \%$ pure, $\mathrm{H}$. Cross Company) was used as the filament material. 
As for $\mathrm{Pb}$ elemental content measurements, all $\mathrm{Pb}$ samples were dissolved in $1 \mu \mathrm{L}$ of $2.5 \mathrm{M} \mathrm{HCl}$ and loaded onto a single Re filament along with $1 \mu \mathrm{L}$ of $0.20 \mathrm{M} \mathrm{H}_{3} \mathrm{PO}_{4}$ and $1 \mu \mathrm{L}$ of silicate gel solution contained $5 \mu \mathrm{g} \mathrm{SiO}{ }_{2}$ [29-31] to enhance $\mathrm{Pb}$ emission. The loading blank in this study was about $0.73 \pm 0.09 \mathrm{pg}(\mathrm{n}=3)$ from the mixture of $1 \mu \mathrm{L}$ of silicate gel $+1 \mu \mathrm{L}$ of $0.20 \mathrm{M} \mathrm{H}_{3} \mathrm{PO}_{4}$. As for $\mathrm{Pb}$ isotopic ratio measurements, the loading and measurement methods were the same as in the above description. The difference was that each chemically purified $\mathrm{Pb}$ sample was split into two batches in a ratio of 1:2. One batch containing $\sim 33 \%$ was measured without adding ${ }^{204} \mathrm{~Pb}-{ }^{207} \mathrm{~Pb}$ double spike. The other batch containing $\sim 67 \%$ was measured adding a suitable amount of ${ }^{204} \mathrm{~Pb}-{ }^{207} \mathrm{~Pb}$ double spike $[29,30]$. All data were acquired when the signal intensities of ${ }^{208} \mathrm{~Pb}$ was higher than $4.5 \times{ }^{-11} \mathrm{~A}$. Each analysis included 100 ratios and was conducted in static multi-collection mode with the collector array shown in Table 3. The tuning speed of the filament current was $400 \mathrm{~mA} / \mathrm{min}$. The ionization temperature of $\mathrm{Pb}$ was about $1220-1300^{\circ} \mathrm{C}$.

Table 3. Configuration for $\mathrm{Pb}$ isotope analysis.

\begin{tabular}{ccccc}
\hline Element & $\mathbf{C}$ & $\mathbf{H 1}$ & $\mathbf{H 2}$ & $\mathbf{H 3}$ \\
\hline $\mathbf{P b}$ & ${ }^{204} \mathrm{~Pb}$ & ${ }^{206} \mathrm{~Pb}$ & ${ }^{207} \mathrm{~Pb}$ & ${ }^{208} \mathrm{~Pb}$ \\
\hline
\end{tabular}

Considerable literature now exists on the use of the double spike methods [29-31,34] since the early 1960s [35] and hence this is not repeated here. The final $\mathrm{Pb}$ isotopic data reduction was conducted off-line using the method reported by Woodhead et al. [31]. After mass fractionation correction using the ${ }^{204} \mathrm{~Pb}-{ }^{207} \mathrm{~Pb}$ double spike method, typical internal precision (2 RSE) was better than $0.004 \%$ for ${ }^{206} \mathrm{~Pb} /{ }^{204} \mathrm{~Pb},{ }^{207} \mathrm{~Pb} /{ }^{204} \mathrm{~Pb}$, and ${ }^{208} \mathrm{~Pb} /{ }^{204} \mathrm{~Pb}$, and $0.002 \%$ for ${ }^{206} \mathrm{~Pb} /{ }^{207} \mathrm{~Pb}$ and ${ }^{208} \mathrm{~Pb} /{ }^{206} \mathrm{~Pb}$ for most samples. NIST SRM 981 was repeatedly measured during all runs. Replicated analyses $(n=8)$ of the Pb reference material NIST SRM 981 with a 20 ng sample size using the ${ }^{204} \mathrm{~Pb}{ }^{207} \mathrm{~Pb}$ double spike technique yielded good external reproducibility of $<0.032 \%$ (2 RSD) for $\mathrm{Pb}$ isotope ratios, e.g., ${ }^{206} \mathrm{~Pb} /{ }^{204} \mathrm{~Pb}=16.933 \pm$ $0.003,{ }^{207} \mathrm{~Pb} / 204 \mathrm{~Pb}=15.485 \pm 0.003,{ }^{208} \mathrm{~Pb} /{ }^{204} \mathrm{~Pb}=36.681 \pm 0.012$, and ${ }^{207} \mathrm{~Pb} /{ }^{206} \mathrm{~Pb}=0.9145 \pm 0.0002$, showing good agreement with published data within analytical error [29-34,36-38].

\section{Results and Discussion}

\subsection{Pb Elemental Concentration Results}

The isotope dilution mass spectrometry (IDMS) method has been recognized as the most important technique for accurate measurements of elemental content at the highest metrological level for more than 50 years. The IDMS method only requires the high precision of isotopic ratios after sample and spike weighing and their complete mixing [39]. In contrast to other analytical techniques, the merit of IDMS is that even part loss of analyte during sample treatment does not affect the accuracy of the analytical result. For this reason, IDMS is considered a benchmark technique of elemental content analysis for CRMs [22,24,25,28,39]. It is especially true for ID combined with TIMS (ID-TIMS method) due to its high precision and accuracy. As to the principle behind single isotope dilution mass spectrometry, detailed descriptions were reported by Krata et al. [24], Vassileva et al. [25], Vogl [39], and Berglund [40]. Our calculation method was similar to these methods. Lead concentration in CA and CFA CRMs can be calculated from Equation (1):

$$
C_{x}=C_{y} \times\left[M_{y} / M_{x}\right] \times\left[R_{y}-R_{x y}\right] /\left[R_{x y}-R_{x}\right] \times\left[\Sigma R_{i x}\right] /\left[\Sigma R_{i y}\right]
$$

where $C_{x}$ is the $\mathrm{Pb}$ elemental concentration of the sample (normally expressed as $\mu \mathrm{g} / \mathrm{g}$ ); $\mathrm{C}_{\mathrm{y}}$ is the $\mathrm{Pb}$ elemental concentration in the spike solution; $\mathrm{M}_{\mathrm{x}}$ and $\mathrm{M}_{\mathrm{y}}$ are the weights of the sample and spike, respectively; $R_{x}$ and $R_{y}$ are the ${ }^{207} \mathrm{~Pb} /{ }^{206} \mathrm{~Pb}$ isotope ratio of the sample and spike, respectively; $R_{x y}$ is the ${ }^{207} \mathrm{~Pb} /{ }^{206} \mathrm{~Pb}$ isotope ratio of the sample-spike mixture; and $\Sigma \mathrm{R}_{\mathrm{ix}}$ and $\Sigma \mathrm{R}_{\mathrm{iy}}$ are the sums of ratios for all $\mathrm{Pb}$ isotopes relative to the reference isotope $\left({ }^{206} \mathrm{~Pb}\right)$ for sample and spike, respectively. 
For the ID-TIMS method, the key factor is to obtain highly reproducible and accurate $\mathrm{Pb}$ isotope ratios. In this case, we chose ${ }^{206} \mathrm{~Pb}$ as the denominator because the mass fractionation of ${ }^{207} \mathrm{~Pb} /{ }^{206} \mathrm{~Pb}$ is small and the reproducibility of ${ }^{207} \mathrm{~Pb} /{ }^{206} \mathrm{~Pb}$ is excellent. For example, the ${ }^{207} \mathrm{~Pb} /{ }^{206} \mathrm{~Pb}$ value for the NIST 981 standard with $20 \mathrm{ng}$ sample size is $0.91384 \pm 0.00038(\mathrm{n}=36,2 \mathrm{SD})$ even without any mass fractionation correction in the last year. Clearly, the reproducibility of ${ }^{207} \mathrm{~Pb} /{ }^{206} \mathrm{~Pb}$ is stable and better than $0.042 \%$ (2 RSD) even without any mass fractionation correction, based on long-term observations in our laboratory. We adopted the linear law to correct mass fractionation for Pb elemental content measurements. In this study, the mass fractionation factor for $\mathrm{Pb}$ is $0.0923 \% / \mathrm{amu}$, which was calculated and normalized to the recommended value $\left({ }^{207} \mathrm{~Pb} /{ }^{206} \mathrm{~Pb}=0.9147\right)$ reported by Woodhead et al. [31].

As shown in Table 4, the $\mathrm{Pb}$ contents of JB-3 and BCR-2 utilizing the ${ }^{207} \mathrm{~Pb}$ single spike method combined with TIMS analysis show a good agreement with previously published data [32,41-45] within uncertainties. This demonstrates our analytical method based on the single ${ }^{207} \mathrm{~Pb}$ spike in conjunction with TIMS to measure $\mathrm{Pb}$ elemental content is reliable and accurate. As shown in Table 4 and Figure 1, the concentration of $\mathrm{Pb}$ in CA and CFA reference materials was found to be $36.74 \pm 0.14 \mu \mathrm{g} / \mathrm{g}$ for GBW08401, $41.12 \pm 0.07 \mu \mathrm{g} / \mathrm{g}$ for GBW11124, $63.85 \pm 0.37 \mu \mathrm{g} / \mathrm{g}$ for GBW11125d, and $47.65 \pm 0.08 \mu \mathrm{g} / \mathrm{g}$ for JCFA-1. Lead contents for these CRMs show a relatively wide range of $36.74-63.85 \mu \mathrm{g} / \mathrm{g}$. The reproducibility ( $\mathrm{n}=4,1 \mathrm{RSD}$ ) of $\mathrm{Pb}$ content is $0.17-0.58 \%$.
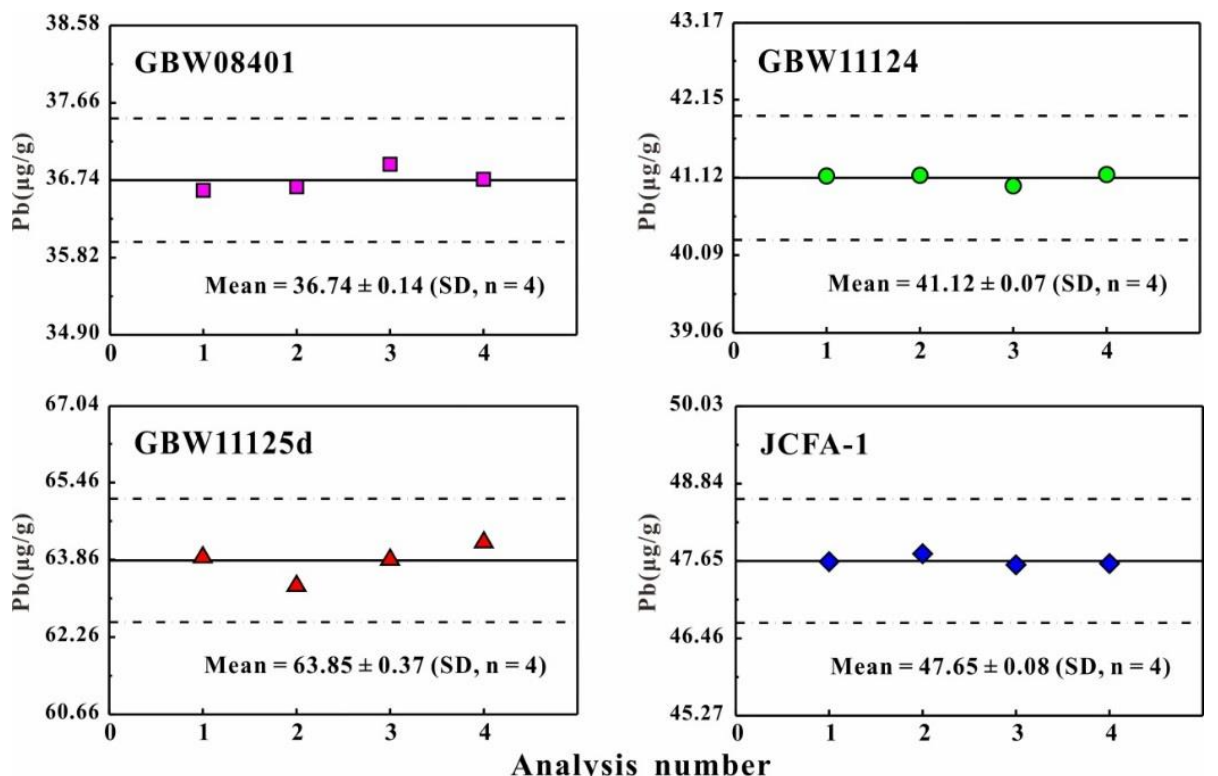

Figure 1. Pb elemental contents in four CFA and CA reference materials. The dashed line area defines the error of $\pm 2 \%$ (1 RSD) of $\mathrm{Pb}$ elemental contents.

Among these reference materials, only Pb content $(47.2 \pm 1.7 \mu \mathrm{g} / \mathrm{g})$ of JFCA- 1 has been measured by atomic absorption spectrometry (AAS), as reported by Terashima et al. [26]. The Pb elemental content of JCFA-1 is $47.65 \pm 0.07 \mu \mathrm{g} / \mathrm{g}$ in this study, showing an excellent agreement with Terashima et al. [26]. This study is the first to report the Pb elemental content for GBW08401, GBW11124, and GBW11125d. It is important to emphasize that our data recorded excellent reproducibility using the ID-TIMS method. Generally, among these CA and CFA reference materials, JCFA-1 and GBW11124 show better reproducibility $(<0.20 \%, 1 \mathrm{RSD})$ of $\mathrm{Pb}$ elemental content and hence are more homogeneous.

\section{2. $\mathrm{Pb}$ isotopic Ratio Results}

As mentioned in Section 2.5, TIMS double spike analysis requires ${ }^{20 x} \mathrm{~Pb} /{ }^{204} \mathrm{~Pb}$ ratios on two filament loads: a "natural" run with unspiked sample and a sample-spiked mixture run. The optimum mixture of sample and spike is the so-called " $\mathrm{Q}$ value", which was calculated as ${ }^{204} \mathrm{~Pb}_{\text {sample }} /{ }^{204} \mathrm{~Pb}_{\text {spike }}$ $=0.10-0.15$ in this study, with a tolerance range of $0.03-0.65[31,34]$ that was regarded as negligible 
uncertainty magnification. Both JB-3 and BCR-2 basalt standards were analyzed to verify the reliability of the sample digestion method, chemical procedure, and TIMS measurement. As shown in Table 5, the $\mathrm{Pb}$ isotopic ratios data for JB-3 and BCR-2 show good agreement with previously published data $[29,30,32,33,36-38,45]$. This demonstrates the whole analysis process as outlined in this paper is reliable.

$\mathrm{Pb}$ isotopic ratios measured by TIMS are listed in Table 5 and shown in Figure 2, along with their individual within-run precision ( $2 \mathrm{SE}$ ). It can be seen that good internal precisions were achieved in each run, which was between \pm 0.0006 and \pm 0.0008 for ${ }^{206} \mathrm{~Pb} /{ }^{204} \mathrm{~Pb}$, between \pm 0.0005 and \pm 0.0008 for ${ }^{207} \mathrm{~Pb} /{ }^{204} \mathrm{~Pb}$, between \pm 0.0012 and \pm 0.0024 for ${ }^{208} \mathrm{~Pb} /{ }^{204} \mathrm{~Pb}$, between \pm 0.00001 and \pm 0.00002 for ${ }^{206} \mathrm{~Pb} /{ }^{207} \mathrm{~Pb}$, and between \pm 0.00002 and \pm 0.00004 for ${ }^{208} \mathrm{~Pb} /{ }^{206} \mathrm{~Pb}$. During data collection, a long-life and stable $\mathrm{Pb}$ ion beam signal was obtained, typically with ${ }^{208} \mathrm{~Pb}$ of $4.5-6.5 \mathrm{~V}$. This demonstrates that the purity of $\mathrm{Pb}$ fractions after chemical separation was appropriate for TIMS measurements.

This study is the first to report $\mathrm{Pb}$ isotopic ratios of reference materials (GBW11125d, GBW11124, and GBW08401), thus no previously published reference values are available for comparison. To obtain high reliable data of $\mathrm{Pb}$ isotope ratios, eight replicate analyses were determined for each of the reference materials (GBW08401, GBW11124, GBW11125d, and JCFA-1). As shown in Table 5 and Figure 2, generally, the external precision reproducibility (2 RSD, $n=8$ ) of Pb isotopic ratios in these CRMs are good, except for GBW11124. GBW11124 shows poor reproducibility, which may be ascribed to either sample inhomogeneity or contamination during processing (crushing and pulverization), although we favor the former interpretation. In comparison to $\mathrm{Sr}$ and $\mathrm{Nd}$ isotope systems, $\mathrm{Pb}$ is more easily contaminated during the original preparation of the CRM samples [32]. As for GBW08401, GBW11125d, and JCFA-1, the external precision (2 RSD) reproducibility of ${ }^{206} \mathrm{~Pb} /{ }^{204} \mathrm{~Pb},{ }^{207} \mathrm{~Pb} /{ }^{204} \mathrm{~Pb}$, ${ }^{208} \mathrm{~Pb} /{ }^{204} \mathrm{~Pb},{ }^{206} \mathrm{~Pb} /{ }^{207} \mathrm{~Pb}$, and ${ }^{208} \mathrm{~Pb} /{ }^{206} \mathrm{~Pb}$ are narrowly variable i.e., $0.018-0.046 \%, 0.022-0.053 \%$, $0.020-0.067 \%, 0.010-0.038 \%$, and $0.016-0.045 \%$, respectively. Generally, ${ }^{206} \mathrm{~Pb} /{ }^{207} \mathrm{~Pb}$ values among the five $\mathrm{Pb}$ isotopic ratios in these CRMs show the best reproducibility $(<0.04 \%, 2 \mathrm{RSD})$, even achieving $0.010 \%$ for GBW08401. 
Table 4. Pb elemental contents in coal fly ash, coal ash and silicate CRMs.

\begin{tabular}{|c|c|c|c|c|c|c|c|c|c|}
\hline CRMs & $\begin{array}{c}\text { GBW08401 } \\
\mathrm{Pb}(\mu \mathrm{g} / \mathrm{g})\end{array}$ & $\begin{array}{l}\text { GBW11124 } \\
\mathrm{Pb}(\mu \mathrm{g} / \mathrm{g})\end{array}$ & $\begin{array}{l}\text { GBW1125d } \\
\mathrm{Pb}(\mu \mathrm{g} / \mathrm{g})\end{array}$ & $\begin{array}{c}\text { JCFA-1 } \\
\mathrm{Pb}(\mu \mathrm{g} / \mathrm{g})\end{array}$ & $\begin{array}{c}\text { Reported } \\
\text { Value }(\mu \mathrm{g} / \mathrm{g})\end{array}$ & $\begin{array}{c}\text { JB-3 } \\
\mathrm{Pb}(\mu \mathrm{g} / \mathrm{g})\end{array}$ & $\begin{array}{c}\text { Reported } \\
\text { Value }(\mu \mathrm{g} / \mathrm{g})\end{array}$ & $\begin{array}{c}\text { BCR-2 } \\
\mathrm{Pb}(\mu \mathrm{g} / \mathrm{g})\end{array}$ & $\begin{array}{c}\text { Reported } \\
\text { Value }(\mu \mathrm{g} / \mathrm{g})\end{array}$ \\
\hline & 36.62 & 41.14 & 63.93 & 47.64 & 47.2 (Ref. 26) & 5.33 & 5.58 (Ref. 41) & 10.95 & 11.02 (Ref. 32) \\
\hline & 36.66 & 41.15 & 63.34 & 47.76 & & 5.34 & 5.04 (Ref. 42) & 10.98 & 10.50 (Ref. 43) \\
\hline & 36.93 & 41.01 & 63.88 & 47.59 & & 5.29 & 5.035 (Ref. 45) & 10.84 & 10.90 (Ref. 44) \\
\hline & 36.75 & 41.16 & 64.24 & 47.61 & & 5.35 & & 10.91 & \\
\hline Mean & 36.74 & 41.12 & 63.85 & 47.65 & & 5.33 & & 10.92 & \\
\hline SD & 0.14 & 0.07 & 0.37 & 0.08 & & 0.03 & & 0.06 & \\
\hline RSD (\%) & 0.38 & 0.17 & 0.58 & 0.17 & & 0.56 & & 0.55 & \\
\hline
\end{tabular}

Table 5. Pb isotope ratios in coal fly ash, coal ash and silicate CRMs.

\begin{tabular}{|c|c|c|c|c|c|c|c|c|c|c|}
\hline CRMs & ${ }^{206} \mathrm{~Pb} /{ }^{204} \mathrm{~Pb}$ & $2 \mathrm{SE}$ & ${ }^{207} \mathrm{~Pb} /{ }^{204} \mathrm{~Pb}$ & $2 \mathrm{SE}$ & ${ }^{208} \mathrm{~Pb} /{ }^{204} \mathrm{~Pb}$ & $2 \mathrm{SE}$ & ${ }^{206} \mathrm{~Pb} /{ }^{207} \mathrm{~Pb}$ & $2 \mathrm{SE}$ & ${ }^{208} \mathrm{~Pb} /{ }^{206} \mathrm{~Pb}$ & $2 \mathrm{SE}$ \\
\hline GBW08401 & 17.9918 & 0.0006 & 15.5114 & 0.0005 & 38.1801 & 0.0014 & 1.15991 & 0.00001 & 2.12209 & 0.00002 \\
\hline GBW08401 & 17.9933 & 0.0007 & 15.5122 & 0.0007 & 38.1816 & 0.0017 & 1.15994 & 0.00002 & 2.12199 & 0.00003 \\
\hline GBW08401 & 17.9903 & 0.0006 & 15.5119 & 0.0005 & 38.1840 & 0.0013 & 1.15978 & 0.00001 & 2.12247 & 0.00002 \\
\hline GBW08401 & 17.9919 & 0.0006 & 15.5126 & 0.0006 & 38.1829 & 0.0015 & 1.15982 & 0.00001 & 2.12223 & 0.00002 \\
\hline GBW08401 & 17.9947 & 0.0007 & 15.5154 & 0.0006 & 38.1895 & 0.0015 & 1.15980 & 0.00001 & 2.12226 & 0.00002 \\
\hline GBW08401 & 17.9948 & 0.0007 & 15.5158 & 0.0006 & 38.1874 & 0.0014 & 1.15978 & 0.00001 & 2.12213 & 0.00002 \\
\hline GBW08401 & 17.9930 & 0.0007 & 15.5134 & 0.0006 & 38.1798 & 0.0016 & 1.15983 & 0.00001 & 2.12193 & 0.00002 \\
\hline GBW08401 & 17.9946 & 0.0008 & 15.5152 & 0.0006 & 38.1890 & 0.0016 & 1.15980 & 0.00002 & 2.12225 & 0.00003 \\
\hline Mean & 17.9931 & & 15.5135 & & 38.1843 & & 1.15983 & & 2.12217 & \\
\hline 2SD & 0.0033 & & 0.0035 & & 0.0078 & & 0.00012 & & 0.00035 & \\
\hline 2RSD (\%) & 0.018 & & 0.022 & & 0.020 & & 0.010 & & 0.016 & \\
\hline GBW11124 & 19.2195 & 0.0007 & 15.6657 & 0.0006 & 39.0419 & 0.0016 & 1.22685 & 0.00001 & 2.03137 & 0.00002 \\
\hline GBW11124 & 19.2306 & 0.0007 & 15.6784 & 0.0006 & 39.0823 & 0.0016 & 1.22657 & 0.00001 & 2.03230 & 0.00002 \\
\hline GBW11124 & 19.2239 & 0.0006 & 15.6696 & 0.0005 & 39.0556 & 0.0012 & 1.22683 & 0.00001 & 2.03161 & 0.00003 \\
\hline GBW11124 & 19.2342 & 0.0008 & 15.6764 & 0.0007 & 39.0724 & 0.0018 & 1.22695 & 0.00002 & 2.03140 & 0.00003 \\
\hline GBW11124 & 19.2137 & 0.0007 & 15.6707 & 0.0005 & 39.0330 & 0.0014 & 1.22609 & 0.00001 & 2.03152 & 0.00002 \\
\hline GBW11124 & 19.2358 & 0.0007 & 15.6783 & 0.0006 & 39.0787 & 0.0015 & 1.22690 & 0.00001 & 2.03157 & 0.00002 \\
\hline GBW11124 & 19.2325 & 0.0006 & 15.6819 & 0.0006 & 39.0881 & 0.0015 & 1.22642 & 0.00001 & 2.03239 & 0.00003 \\
\hline
\end{tabular}


Table 5. Cont.

\begin{tabular}{|c|c|c|c|c|c|c|c|c|c|c|}
\hline CRMs & ${ }^{206} \mathrm{~Pb} /{ }^{204} \mathrm{~Pb}$ & $2 \mathrm{SE}$ & ${ }^{207} \mathrm{~Pb} /{ }^{204} \mathrm{~Pb}$ & $2 \mathrm{SE}$ & ${ }^{208} \mathrm{~Pb} /{ }^{204} \mathrm{~Pb}$ & $2 \mathrm{SE}$ & ${ }^{206} \mathrm{~Pb} /{ }^{207} \mathrm{~Pb}$ & $2 \mathrm{SE}$ & ${ }^{208} \mathrm{~Pb} /{ }^{206} \mathrm{~Pb}$ & $2 \mathrm{SE}$ \\
\hline GBW11124 & 19.2354 & 0.0008 & 15.6810 & 0.0006 & 39.0862 & 0.0015 & 1.22667 & 0.00001 & 2.03200 & 0.00002 \\
\hline Mean & 19.2282 & & 15.6753 & & 39.0673 & & 1.22666 & & 2.03177 & \\
\hline 2SD & 0.0164 & & 0.0117 & & 0.0423 & & 0.00059 & & 0.00081 & \\
\hline 2RSD (\%) & 0.086 & & 0.075 & & 0.108 & & 0.048 & & 0.040 & \\
\hline GBW11125d & 18.4685 & 0.0007 & 15.6435 & 0.0006 & 38.6202 & 0.0016 & 1.18058 & 0.00001 & 2.09114 & 0.00002 \\
\hline GBW11125d & 18.4774 & 0.0007 & 15.6445 & 0.0007 & 38.6250 & 0.0017 & 1.18108 & 0.00002 & 2.09040 & 0.00003 \\
\hline GBW11125d & 18.4682 & 0.0007 & 15.6427 & 0.0006 & 38.6202 & 0.0015 & 1.18063 & 0.00001 & 2.09117 & 0.00002 \\
\hline GBW11125d & 18.4762 & 0.0006 & 15.6486 & 0.0005 & 38.6320 & 0.0013 & 1.18069 & 0.00001 & 2.09091 & 0.00002 \\
\hline GBW11125d & 18.4767 & 0.0007 & 15.6479 & 0.0006 & 38.6430 & 0.0016 & 1.18078 & 0.00001 & 2.09145 & 0.00003 \\
\hline GBW11125d & 18.4791 & 0.0007 & 15.6458 & 0.0006 & 38.6283 & 0.0015 & 1.18109 & 0.00001 & 2.09038 & 0.00002 \\
\hline GBW11125d & 18.4775 & 0.0008 & 15.6504 & 0.0008 & 38.6378 & 0.0018 & 1.18065 & 0.00001 & 2.09107 & 0.00003 \\
\hline GBW11125d & 18.4731 & 0.0007 & 15.6489 & 0.0006 & 38.6407 & 0.0016 & 1.18047 & 0.00001 & 2.09173 & 0.00002 \\
\hline Mean & 18.4746 & & 15.6466 & & 38.6309 & & 1.18075 & & 2.09103 & \\
\hline 2SD & 0.0084 & & 0.0056 & & 0.0179 & & 0.00045 & & 0.00094 & \\
\hline 2RSD (\%) & 0.046 & & 0.036 & & 0.046 & & 0.038 & & 0.045 & \\
\hline JCFA-1 & 18.3987 & 0.0007 & 15.5652 & 0.0006 & 38.4265 & 0.0014 & 1.18204 & 0.00001 & 2.08854 & 0.00002 \\
\hline JCFA-1 & 18.3899 & 0.0007 & 15.5602 & 0.0006 & 38.4073 & 0.0014 & 1.18186 & 0.00001 & 2.08850 & 0.00002 \\
\hline JCFA-1 & 18.3934 & 0.0007 & 15.5594 & 0.0006 & 38.4089 & 0.0015 & 1.18214 & 0.00001 & 2.08819 & 0.00002 \\
\hline JCFA-1 & 18.3948 & 0.0006 & 15.5603 & 0.0005 & 38.4124 & 0.0013 & 1.18216 & 0.00001 & 2.08822 & 0.00002 \\
\hline JCFA-1 & 18.4032 & 0.0007 & 15.5718 & 0.0006 & 38.4456 & 0.0016 & 1.18183 & 0.00001 & 2.08907 & 0.00002 \\
\hline JCFA-1 & 18.3953 & 0.0007 & 15.5603 & 0.0006 & 38.4095 & 0.0015 & 1.18220 & 0.00001 & 2.08801 & 0.00002 \\
\hline JCFA-1 & 18.3970 & 0.0007 & 15.5640 & 0.0007 & 38.4238 & 0.0017 & 1.18203 & 0.00001 & 2.08860 & 0.00003 \\
\hline JCFA-1 & 18.3985 & 0.0006 & 15.5636 & 0.0006 & 38.4228 & 0.0013 & 1.18215 & 0.00001 & 2.08837 & 0.00002 \\
\hline Mean & 18.3964 & & 15.5631 & & 38.4196 & & 1.18205 & & 2.08844 & \\
\hline 2SD & 0.0080 & & 0.0082 & & 0.0259 & & 0.00028 & & 0.00065 & \\
\hline 2RSD (\%) & 0.043 & & 0.053 & & 0.067 & & 0.024 & & 0.031 & \\
\hline \multicolumn{11}{|l|}{ JCFA-1 ref value } \\
\hline Ref. 36 & 18.399 & & 15.565 & & 38.426 & & 1.18208 & & 2.08842 & \\
\hline JB-3 & 18.2932 & 0.0007 & 15.5338 & 0.0006 & 38.2436 & 0.0015 & 1.17764 & 0.00001 & 2.09059 & 0.00002 \\
\hline JB-3 & 18.2936 & 0.0007 & 15.5357 & 0.0006 & 38.2479 & 0.0016 & 1.17752 & 0.00001 & 2.09079 & 0.00003 \\
\hline JB-3 & 18.2928 & 0.0008 & 15.5354 & 0.0008 & 38.2430 & 0.0020 & 1.17749 & 0.00002 & 2.09060 & 0.00003 \\
\hline JB-3 & 18.2936 & 0.0008 & 15.5365 & 0.0008 & 38.2480 & 0.0020 & 1.17746 & 0.00002 & 2.09078 & 0.00003 \\
\hline JB-3 & 18.2899 & 0.0007 & 15.5310 & 0.0007 & 38.2327 & 0.0017 & 1.17763 & 0.00001 & 2.09038 & 0.00003 \\
\hline
\end{tabular}


Table 5. Cont.

\begin{tabular}{|c|c|c|c|c|c|c|c|c|c|c|}
\hline CRMs & ${ }^{206} \mathrm{~Pb} /{ }^{204} \mathrm{~Pb}$ & $2 \mathrm{SE}$ & ${ }^{207} \mathrm{~Pb} /{ }^{204} \mathrm{~Pb}$ & $2 \mathrm{SE}$ & ${ }^{208} \mathrm{~Pb} /{ }^{204} \mathrm{~Pb}$ & $2 \mathrm{SE}$ & ${ }^{206} \mathrm{~Pb} /{ }^{207} \mathrm{~Pb}$ & $2 \mathrm{SE}$ & ${ }^{208} \mathrm{~Pb} /{ }^{206} \mathrm{~Pb}$ & $2 \mathrm{SE}$ \\
\hline JB-3 & 18.2923 & 0.0006 & 15.5349 & 0.0005 & 38.2413 & 0.0013 & 1.17750 & 0.00001 & 2.09056 & 0.00002 \\
\hline Mean & 18.2926 & 0.0007 & 15.5346 & 0.0006 & 38.2427 & 0.0015 & 1.17754 & 0.00001 & 2.09062 & 0.00002 \\
\hline 2SD & 0.0028 & & 0.0039 & & 0.0112 & & 0.00016 & & 0.00031 & \\
\hline 2RSD (\%) & 0.015 & & 0.025 & & 0.029 & & 0.014 & & 0.015 & \\
\hline \multicolumn{11}{|c|}{ JB-3 ref values } \\
\hline Ref. 33 & 18.2942 & & 15.5355 & & 38.2496 & & 1.17757 & & 2.09080 & \\
\hline Ref. 37 & 18.2592 & & 15.5356 & & 38.2506 & & 1.17531 & & 2.09487 & \\
\hline Ref. 29 & 18.2900 & & 15.5310 & & 38.2320 & & 1.17764 & & 2.09032 & \\
\hline Ref. 30 & 18.2997 & & 15.5228 & & 38.2441 & & 1.17889 & & 2.08988 & \\
\hline Ref. 36 & 18.2910 & & 15.5403 & & 38.2500 & & 1.17700 & & 2.09119 & \\
\hline Ref. 45 & 18.2954 & & 15.5380 & & 38.2516 & & 1.17746 & & 2.09078 & \\
\hline Mean & 18.2883 & & 15.5339 & & 38.2463 & & 1.17731 & & 2.09131 & \\
\hline BCR-2 & 18.7523 & 0.0006 & 15.6184 & 0.0005 & 38.7105 & 0.0012 & 1.20065 & 0.00001 & 2.06431 & 0.00003 \\
\hline BCR-2 & 18.7561 & 0.0008 & 15.6212 & 0.0009 & 38.7168 & 0.0024 & 1.20068 & 0.00002 & 2.06422 & 0.00004 \\
\hline BCR-2 & 18.7527 & 0.0007 & 15.6248 & 0.0008 & 38.7162 & 0.0023 & 1.20019 & 0.00002 & 2.06457 & 0.00003 \\
\hline BCR-2 & 18.7477 & 0.0008 & 15.6161 & 0.0006 & 38.7076 & 0.0015 & 1.20053 & 0.00001 & 2.06466 & 0.00002 \\
\hline BCR-2 & 18.7517 & 0.0007 & 15.6245 & 0.0006 & 38.7268 & 0.0015 & 1.20015 & 0.00001 & 2.06524 & 0.00002 \\
\hline BCR-2 & 18.7531 & 0.0006 & 15.6195 & 0.0005 & 38.7141 & 0.0013 & 1.20063 & 0.00001 & 2.06441 & 0.00002 \\
\hline Mean & 18.7523 & & 15.6207 & & 38.7153 & & 1.20047 & & 2.06457 & \\
\hline 2SD & 0.0055 & & 0.0069 & & 0.0133 & & 0.00048 & & 0.00074 & \\
\hline 2RSD (\%) & 0.029 & & 0.044 & & 0.034 & & 0.040 & & 0.036 & \\
\hline \multicolumn{11}{|c|}{ BCR-2 ref values } \\
\hline Ref. 29 & 18.7520 & & 15.6200 & & 38.7150 & & 1.20051 & & 2.06458 & \\
\hline Ref. 30 & 18.7580 & & 15.6240 & & 38.7210 & & 1.20059 & & 2.06424 & \\
\hline Ref. 32 & 18.7529 & & 15.6250 & & 38.7237 & & 1.20019 & & 2.06494 & \\
\hline Ref. 38 & 18.7540 & & 15.6230 & & 38.7230 & & 1.20041 & & 2.06479 & \\
\hline Mean & 18.7542 & & 15.6230 & & 38.7207 & & 1.20042 & & 2.06464 & \\
\hline
\end{tabular}

SD: Standard deviation, RSD: Relative Standard Deviation. 

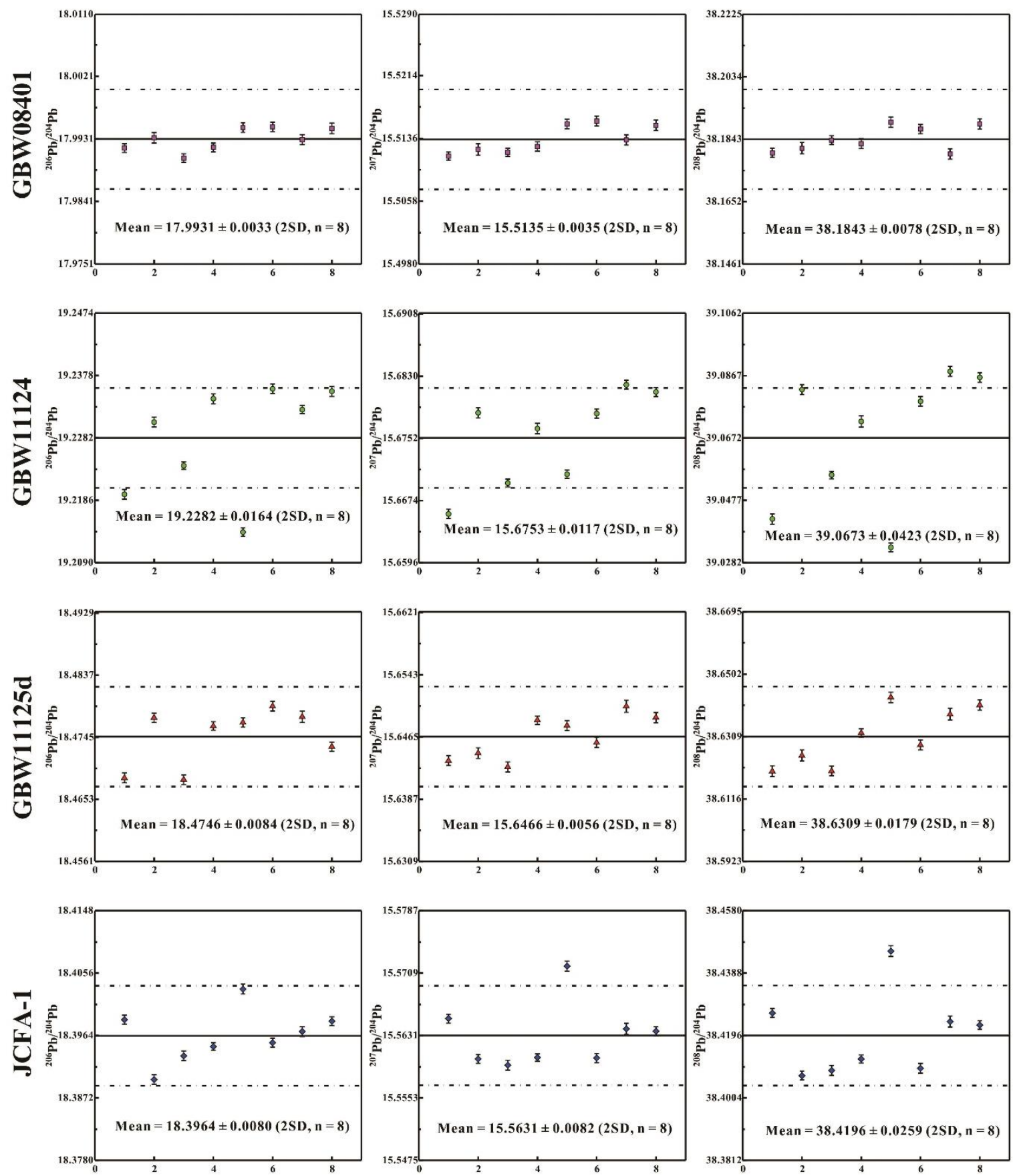

Analysis number

Figure 2. $\mathrm{Pb}$ isotope ratios in four $\mathrm{CFA}$ and $\mathrm{CA}$ reference materials. The dashed line area defines the error of $\pm 0.04 \%$ (2 RSD) of $\mathrm{Pb}$ isotope ratios.

Among these reference materials, only $\mathrm{Pb}$ isotope ratios of JFCA- 1 have been measured by multi-collector-inductively coupled plasma-mass spectrometry (MC-ICP-MS) [36]. However, Hattori et al. [36] only conducted one analysis of JCFA-1 and no repeated measurements were undertaken. Hence, it is unknown whether the $\mathrm{Pb}$ isotope compositions of JCFA-1 are homogeneous. As shown in Table 5, our repeated measurement data $(n=8)$ for JCFA-1 demonstrate that it is homogeneous for $\mathrm{Pb}$ isotope ratios, being in good agreement with the data reported by Hattori et al. [36]. 


\section{Conclusions}

Evaluating the accuracy and precision of $\mathrm{Pb}$ elemental content and isotopic values of unknown CFA and CA samples requires the use of characterized CRMs with similar matrices being analyzed. In this study, high precision $\mathrm{Pb}$ isotope ratio determinations were made on four commercially available coal fly ash as well as coal ash reference materials. The external precision of $\mathrm{Pb}$ isotope ratios (except for GBW11124) is generally better than $0.05 \%$ ( $2 \mathrm{RSD}, \mathrm{n}=8$ ), varying from $0.010 \%$ to $0.067 \%$ ( $2 \mathrm{RSD}$, $\mathrm{n}=8)$ for all $\mathrm{Pb}$ isotope ratios. The reproducibility of $\mathrm{Pb}$ contents is better than $0.60 \%(1 \mathrm{RSD}, \mathrm{n}=4)$. These results indicate that JCFA-1, GBW08401, GBW11124, and GBW11125d can be used as reference materials for validating $\mathrm{Pb}$ isotope ratios and $\mathrm{Pb}$ elemental contents in coal fly ash and coal ash samples. Among these reference materials, JCFA- 1 and GBW11124 show the best reproducibility $(<0.20 \%, 1$ RSD) for $\mathrm{Pb}$ elemental contents and GBW08401 shows the best reproducibility $(<0.022 \%, 2 \mathrm{RSD})$ for $\mathrm{Pb}$ isotope ratios. We consider this dataset of $\mathrm{Pb}$ elemental contents and $\mathrm{Pb}$ isotopes, when combined with our previously published $\mathrm{Rb}-\mathrm{Sr}$ and $\mathrm{Sm}-\mathrm{Nd}$ elemental content and Sr-Nd isotope data [22] for the same suite of CRMs, will provide fundamental support for tracing the emission pathway of CA and CFA in environmental science.

Author Contributions: Methodology and writing—review and editing, C.L.; data collection, H.W., Y.L., X.W., and Z.C.; and funding acquisition, J.G. and C.L.

Funding: This work was jointly supported by the National Natural Science Foundation of China (grants 41490632 and 41673061), the Instrument Function Developing Project of the Chinese Academy of Sciences (IGG201803), and the Research Start-up Project for Introduced Talent of Yunnan University (No. 20190043).

Acknowledgments: We would like to thank Li Hongyan and Li Weiyi for sample preparation and experimental assistance. We thank Wilde Simon A (Curtin University) for English improvement of this article.

Conflicts of Interest: The author declares no conflict of interest.

\section{References}

1. Stigliani, W.M.; Doelman, P.; Salomons, W.; Schulin, R.; Schmidt, G.R.B.; Van der Zee, S.E. Chemical time bombs: Predicting the unpredictable. Environment 1991, 33, 26-30. [CrossRef]

2. Fang, T.; Liu, G.J.; Zhou, C.C.; Sun, R.Y.; Chen, J.; Wu, D. Lead in Chinese coals: Distribution, modes of occurrence, and environmental effects. Environ. Geochem. Health 2014, 36, 563-581. [CrossRef] [PubMed]

3. Bi, X.Y.; Li, Z.G.; Wang, S.X.; Zhang, L.; Xu, R.; Liu, J.L.; Yang, H.M.; Guo, M.Z. Lead Isotopic Compositions of Selected Coals, $\mathrm{Pb} / \mathrm{Zn}$ Ores and Fuels in China and the Application for Source Tracing. Environ. Sci. Technol. 2017, 51, 13502-13508. [CrossRef] [PubMed]

4. IEA. Table 1.8: World Consumption of Primary Energy by Energy Type and Selected Country Groups,1980-2006. In International Energy Annual 2006; US Energy Information Administration: Washington, DC, USA, 2008.

5. IEA (International Energy Agency). World Energy Outlook 2017. Available online: http://www.iea.org/ weo2017/ (accessed on 14 November 2017).

6. Maggio, G.; Cacciola, G. When will oil, narural gas, and coal peak? Fuel 2012, 98, 111-123. [CrossRef]

7. Yao, Z.T.; Ji, X.S.; Sarker, P.K.; Tang, J.H.; Ge, L.Q.; Xia, M.S.; Xi, Y.Q. A comprehensive review on the applications of coal fly ash. Earth-Sci. Rev. 2015, 141, 105-121. [CrossRef]

8. Li, Q.; Cheng, H.; Zhou, T.; Lin, C.; Guo, S. The estimated atmospheric lead emissions in China, 1990干2009. Atmos. Environ. 2012, 60, 1-8. [CrossRef]

9. Oliveira, M.L.S.; Boit, K.; Pacheco, F.; Teixeira, E.C.; Schneider, I.L.; Crissien, T.J.; Pinto, D.C.; Oyaga, R.M.; Silva, L.F.O. Multifaceted processes controlling the distribution of hazardous compounds in the spontaneous combustion of coal and the effect of these compounds on human health. Environ. Res. 2018, 160, 562-567. [CrossRef]

10. Ruhl, L.; Vengosh, A.; Dwyer, G.S.; Hsu-Kim, H.; Schwartz, G.; Romanski, A.; Smith, S.D. The impact of coal combustion residue effluent on water resources: A North Carolina example. Environ. Sci. Technol. 2012, 46, 12226-12233. [CrossRef] 
11. Ruhl, L.; Vengosh, A.; Dwyer, G.S.; Hsu-Kim, H.; Deonarine, A.; Bergin, M.; Kravchenko, J. Survey of the potential environmental and health impacts in the immediate aftermath of the coal ash spill in Kingston, Tennessee. Environ. Sci. Technol. 2009, 43, 6326-6333. [CrossRef]

12. Silva, L.F.O.; Daboit, K.; Sampaio, C.H.; Jasper, A.; Andrade, M.L.; Kostova, I.J.; Waanders, F.B.; Henke, K.R.; Hower, J.C. The occurrence of hazardous volatile elements and nanoparticles in bulgarian coal fly ashes and the effect on human health exposure. Sci. Total Environ. 2012, 416, 513-526. [CrossRef]

13. Rodriguez-Iruretagoiena, A.; Vallejuelo, S.F.O.D.; Gredilla, A.; Ramos, C.G.; Oliveira, M.L.S.; Arana, G.; Diego, A.D.; Madariaga, J.M.; Silva, L.F.O. Fate of hazardous elements in agricultural soils surrounding a coal power plant complex from Santa Catarina (Brazil). Sci. Total Environ. 2015, 508, 374-382. [CrossRef] [PubMed]

14. Martinello, K.; Oliveira, M.L.S.; Molossi, F.A.; Ramos, C.G.; Teixeira, E.C.; Kautzmann, R.M.; Silva, L.F.O. Direct identification of hazardous elements in ultra-fine and nanominerals from coal fly ash produced during diesel co-firing. Sci. Total Environ. 2014, 470, 444-452. [CrossRef] [PubMed]

15. Sajwan, K.S.; Alva, A.K.; Keefer, R.F. Chemistry of Trace Elements in Fly Ash; Springer Science+Business Media: New York, NY, USA, 2003.

16. Wei, B.G.; Yang, L.S. A review of heavy metal contaminations in urban soils, urban road dusts and agricultural soils from China. Microchem. J. 2010, 94, 99-107. [CrossRef]

17. Harkness, J.S.; Ruhl, L.S.; Millot, R.; Kloppman, W.; Hower, J.C.; Hsu-Kim, H.; Vengosh, A. Lithium isotope fingerprints in coal and coal combustion residuals from the United States. Prog. Earth Planet. Sci. 2015, 13, 134-137. [CrossRef]

18. Sun, R.Y.; Sonke, J.E.; Heimbürger, L.E.; Belkin, H.E.; Liu, G.J.; Shome, D.; Cukrowska, E.; Liousse, C.; Pokrovsky, O.S.; Streets, D.G. Mercury Stable Isotope Signatures of World Coal Deposits and Historical Coal Combustion Emissions. Environ. Sci. Technol. 2014, 48, 7660-7668. [CrossRef]

19. Ruhl, L.S.; Dwyer, G.S.; Hsu-Kim, H.; Hower, J.C.; Vengosh, A. Boron and strontium isotopic characterization of coal combustion residuals: Validation of new environmental tracers. Environ. Sci. Technol. 2014, 48, 14790-14798. [CrossRef]

20. Straughan, I.R.; Elseewi, A.A.; Page, A.L.; Kaplan, I.R.; Hurst, R.W.; Davis, T.E. Fly ash-derived strontium as an index to monitor deposition from coal-fired power plants. Science 1981, 212, 1267-1269. [CrossRef]

21. Hurst, R.W.; Davis, T.E. Strontium isotopes as tracers of airborne flyash from coal-fired power plants. Environ. Geol. 1981, 3, 363-367. [CrossRef]

22. Li, C.F.; Wu, H.Q.; Chu, Z.Y.; Wang, X.C.; Guo, J.H.; Li, Y.L. Precise determination of radiogenic $\mathrm{Sr}$ and $\mathrm{Nd}$ isotopic ratios and $\mathrm{Rb}, \mathrm{Sr}, \mathrm{Sm}, \mathrm{Nd}$ elemental concentrations in four coal ash and coal flfly ash reference materials using isotope dilution thermal ionization mass spectrometry. Microchem. J. 2019, 146, 906-913. [CrossRef]

23. Komárek, M.; Ettler, V.; Chrastný, V.; Mihaljevič, M. Lead isotopes in environmental sciences: A review. Environ. Int. 2008, 34, 562-577. [CrossRef]

24. Krata, A.A.; Wojciechowski, M.; Kalabun, M.; Bulska, E. Reference measurements of cadmium and lead contents in candidates for new environmental certified materials by isotope dilution inductively coupled plasma mass spectrometry. Microchem. J. 2018, 142, 36-42. [CrossRef]

25. Vassileva, E.; Wysocka, I.; Betti, M. Reference measurements for cadmium, copper, mercury, lead, zinc and methyl mercury mass fractions in scallop sample by isotope dilution inductively coupled plasma mass spectrometry. Microchem. J. 2014, 116, 197-205. [CrossRef]

26. Terashima, S.; Taniguchi, M.; Mikoshiba, M.; Imai, N. Preparation of Two New GSJ Geochemical Reference Materials: Basalt JB-1b and Coal Fly Ash JCFA-1. Geostand. Newsl. 1998, 22, 113-117. [CrossRef]

27. Halmosa, P.; Borsze'ki, J.; Szabó, S.; Halmos, E. Direct analysis of fly ash materials by inductively coupled plasma atomic emission spectrometry using slurry nebulization. Microchem. J. 2005, 79, 25-28. [CrossRef]

28. Mketo, N.; Nomngongo, P.N.; Ngila, J.C. An innovative microwave-assisted digestion method with diluted hydrogen peroxide for rapid extraction of trace elements in coal samples followed by inductively coupled plasma-mass spectrometry. Microchem. J. 2016, 124, 201-208. [CrossRef]

29. Li, C.F.; Chu, Z.Y.; Guo, J.H.; Li, Y.L.; Yang, Y.H.; Li, X.H. A rapid single column separation scheme for high-precision $\mathrm{Sr}-\mathrm{Nd}-\mathrm{Pb}$ isotopic analysis in geological samples using thermal ionization mass spectrometry. Anal. Methods 2015, 7, 4793-4802. [CrossRef] 
30. Li, C.F.; Wang, X.C.; Guo, J.H.; Chu, Z.Y.; Feng, L.J. Rapid separation scheme of Sr, Nd, Pb, and Hf from a single rock digest using a tandem chromatography column prior to isotope ratio measurements by mass spectrometry. J. Anal. Spectrom. 2016, 31, 1150-1159. [CrossRef]

31. Woodhead, J.D.; Volker, F.; Mcculloch, M.T. Routine lead isotope determinations using a lead-207-lead-204 double spike: A long-term assessment of analytical precision and accuracy. Analyst 1995, 120, 35-39. [CrossRef]

32. Weis, D.; Kieffer, B.; Maerschalk, C.; Barling, J.; De, J.J.; Williams, G.A.; Hanano, D.; Pretorius, W.; Mattielli, N.; Scoates, J.S.; et al. High-precision isotopic characterization of USGS reference materials by TIMS and MC-ICP-MS. Geochem. Geophys. Geosyst. 2006, 7. [CrossRef]

33. Fourny, A.; Weis, D.; Scoates, J.S. Comprehensive Pb-Sr-Nd-Hf isotopic, trace element, and mineralogical characterization of mafic to ultramafic rock reference materials. Geochem. Geophys. Geosyst. 2016, 17, 739-773. [CrossRef]

34. Taylor, R.N.; Ishizuka, O.; Michalik, A.; Milton, J.A.; Croudace, I.W. Evaluating the precision of Pb isotope measurement by mass spectrometry. J. Anal. Spectrom. 2015, 30, 198-213. [CrossRef]

35. Dodson, M.H. A theoretical study of the use of internal standards for precise isotopic analysis by the surface ionization technique: Part I-General first-order algebraic solutions. J. Sci. Instrum. 1963, 40, 289-295. [CrossRef]

36. Hattori, M.; Takaku, Y.; Shimamura, T. Novel rapid separation of lead using highly selective resin for measurement of precise lead isotope ratio and its application to geochemical reference samples. Bunseki Kagaku 2008, 57, 113-121. [CrossRef]

37. Pin, C.; Gannoun, A.; Dupont, A. Rapid, simultaneous separation of $\mathrm{Sr}, \mathrm{Pb}$, and $\mathrm{Nd}$ by extraction chromatography prior to isotope ratios determination by TIMS and MC-ICP-MS. J. Anal. At. Spectrom. 2014, 29, 1858-1870. [CrossRef]

38. Woodhead, J.D.; Hergt, J.M. Pb-isotope analyses of USGS reference materials. Geostand. Newsl. J. Geostand. Geoanal. 2000, 24, 33-38. [CrossRef]

39. Vogl, J. Characterisation of reference materials by isotope dilution mass spectrometry. J. Anal. Spectrom. 2007, 22, 475-492. [CrossRef]

40. Berglund, M. Introduction to Isotope Dilution Mass Spectrometry (IDMS). In Handbook of Stable Isotope Analytical Techniques; De Groot, P., Ed.; Elsevier: Amsterdam, The Netherlands, 2004; Volume 1, pp. 820-834.

41. Imai, N.; Terashima, S.; Itoh, S.; Ando, A. 1994 compilation of analytical data for minor and trace elements in seventeen GSJ geochemical reference samples, “Igneous Rock Series”. Geostand. Newsl. J. Geostand. Geoanal. 1995, 19, 135-213. [CrossRef]

42. Dulski, P. Reference Materials for Geochemical Studies: New Analytical Data by ICP-MS and Critical Discussion of Reference Values. Geostand. Newsl. J. Geostand. Geoanal. 2001, 25, 87-125. [CrossRef]

43. Cotta, A.J.B.; Enzweiler, J. Classical and New Procedures of Whole Rock Dissolution for Trace Element Determination by ICP-MS. Geostand. Geoanal. Res. 2012, 36, 27-50. [CrossRef]

44. Stracke, A.; Palme, H.; Gellissen, M.; Munker, C.; Kleine, T.; Birbaum, K.; Gunther, D.; Bourdon, B.; Zipfel, J. Refractory element fractionation in the Allende meteorite: Implications for solar nebula condensation and the chondritic composition of planetary bodies. Geochim. Cosmochim. Acta 2012, 85, 114-141. [CrossRef]

45. Kuritani, T.; Usui, T.; Yokoyama, T.; Nakamura, E. Accurate Isotopic and Concentration Analyses of Small Amounts of $\mathrm{Pb}$ Using Isotope Dilution Coupled with the Double Spike Technique. Geostand. Geoanal. Res. 2006, 30, 209-220. [CrossRef]

(C) 2019 by the authors. Licensee MDPI, Basel, Switzerland. This article is an open access article distributed under the terms and conditions of the Creative Commons Attribution (CC BY) license (http://creativecommons.org/licenses/by/4.0/). 